\title{
Leymeriaster campestris, a new early Campanian hemiasterid echinoid from southern Limburg, the Netherlands ${ }^{*}$
}

\author{
R.W.J.M. van der Ham ${ }^{1,}{ }^{*}$, J.W.M. Jagt ${ }^{2}$ \& H.J. Janssens ${ }^{3}$ \\ 1 Piet Heinstraat 6, NL-2628 RK Delft, the Netherlands. \\ 2 Natuurhistorisch Museum Maastricht, de Bosquetplein 6-7, NL-6211 KJ Maastricht, the Netherlands. \\ 3 Rijksweg 97, NL-6271 AD Gulpen, the Netherlands. \\ * Corresponding author. Email: ham@nhn.leidenuniv.nl.
}

Manuscript received: October 2010; accepted: April 2011

\begin{abstract}
In the type area of the Maastrichtian Stage (northeast Belgium, southeast Netherlands), two species of the rare hemiasterid echinoid genus Leymeriaster were known to date. Here we describe a third, L. campestris sp. nov., from the so-called 'Laagje van Müller' (Gemmenich Member, Vaals Formation) at Vaals-Eschberg, southern Limburg (the Netherlands), which is of early Campanian age. It differs from its late Maastrichtian congeners in the area, L. maestrichtensis and L. eluvialis, in that the pore pairs in the frontal groove of ambulacrum III are not in small depressions and the adjacent interambulacral margins are not thickened, raised and/or overhanging. It differs from L. maestrichtensis by the lack of a clear notch in the ambitus in ambulacrum III, and from L. eluvialis in the presence of a distinctly longer groove in ambulacrum III. Leymeriaster campestris sp. nov. is the first undoubted species of Campanian Leymeriaster known from northwest Europe.
\end{abstract}

Keywords: Echinoidea, Hemiasteridae, Late Cretaceous, the Netherlands, new species

\section{Introduction}

In the type area of the Maastrichtian Stage (northeast Belgium, southeast Netherlands), hemiasterids are common constituents of Late Cretaceous echinoid faunas, in particular those of late Maastrichtian age. Until now, two species of the genus Leymeriaster were known from this area, namely $L$. maestrichtensis (Schlüter, 1897), which ranges through most of the Maastricht Formation (Gronsveld to Meerssen members; see Meijer, 1955; Jagt, 2000a) and L. eluvialis Van der Ham, 1995, which in part overlaps in range with $L$. maestrichtensis but is also known from the underlying Gulpen Formation (Lanaye Member). A third, unnamed species was first recognised in 1992; previous references to this form were in open nomenclature (Van der Ham \& Jagt, 1998; Jagt, 2000a). It is here described in full and formally named. All material available originates from the so-called 'Laagje van Müller' (i.e., Müller's Bed), which in 1987 was temporarily exposed in an outcrop at the Eschberg, southwest of the village of Vaals (southeast Netherlands). 'Müller's Bed' is a highly fossiliferous level within the early Campanian Vaals Formation, which became renowned in the mid-nineteenth century for its exquisitely preserved silicified molluscs (Müller, 1847, 1851, 1859; Holzapfel, 1887-1889; Felder, 1980; Kennedy \& Jagt, 1995; Felder \& Bosch, 2000). In later years, this classic exposure could no longer be traced, and only after decades of searching in vain was the bed finally relocated in 1987 when road extension works at the Eschberg near Vaals were carried out (Felder, 1987). Several specimens of the new species of Leymeriaster were collected, together with thousands of other macrofossils (see also Van Birgelen, 1989; Jagt, 2000b).

\section{Locality and stratigraphy}

The temporary exposure of 'Müller's Bed' in 1987 (outcrop 62D-96) was situated along the Randweg (bypass) across the Eschberg, a hill southwest of Vaals (co-ordinates $50^{\circ} 46^{\prime} 5.46^{\prime \prime} \mathrm{N}$,

* In: Jagt, J.W.M., Jagt-Yazykova, E.A. \& Schins, W.J.H. (eds): A tribute to the late Felder brothers - pioneers of Limburg geology and prehistoric archaeology. 
$6^{\circ} 0$ '31.71" E; see Fig. 1). 'Müller's Bed' is just below the so-called Vaalsbroek Horizon, within the Gemmenich Member, in the lower portion of the Vaals Formation (see Fig. 2; compare Felder \& Bosch, 2000, fig. 3.18). On coleoid and ammonoid cephalopod evidence, this part of the sequence is of earliest Campanian age (lingua/quadrata Zone sensu germanico; see Jagt, 1999).

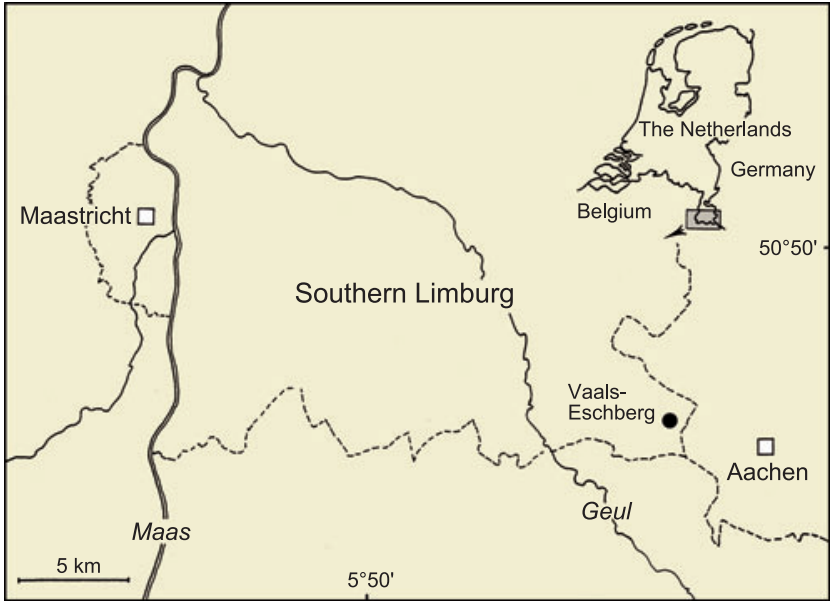

Fig. 1. Map of southern Limburg (the Netherlands) and contiguous areas, showing the locality of Vaals-Eschberg.

\section{Material and associated echinoid species}

Within a short time span, during proceeding road works, several more or less complete specimens and a number of fragments of Leymeriaster were collected. Four specimens are held in collections at the Natuurhistorisch Museum Maastricht (VG 3047 (W.M. Felder Collection), NHMM 1996 001, NHMM 2010164 (ex W.M. Felder Collection) and NHMM 2011014 (ex H.J. Janssens Collection, VG.5441)). Two other tests and six fragments are in the private collection of the third author. We know of no previously collected material, nor are we familiar with any unambiguous records in the literature. Records of spatangoid echinoids by Debey (1849) and Beissel (1886) for the Vaals Formation in the neighbourhood of Vaals (see list of synonyms below) might refer to our new species, but voucher specimens could not be traced.

Together with the new Leymeriaster species, specimens of four other echinoid taxa have been recognised at Vaals-Eschberg, namely Gauthieria pseudoradiata auctt. (non Schlüter, 1883?), Diplodetus sp., Hemiaster gr. aquisgranensis Schlüter, 1899 and Cardiaster aff. granulosus (Goldfuss, 1829). The last-named species was considered conspecific with C. cordiformis (Woodward, 1833) by Smith \& Wright (2003, p. 491), albeit with a query.

\section{Systematic palaeontology}

Order Spatangoida Agassiz, 1840

Family Hemiasteridae H.L. Clark, 1917

Genus Leymeriaster Lambert in Lambert \& Thiéry, 1924

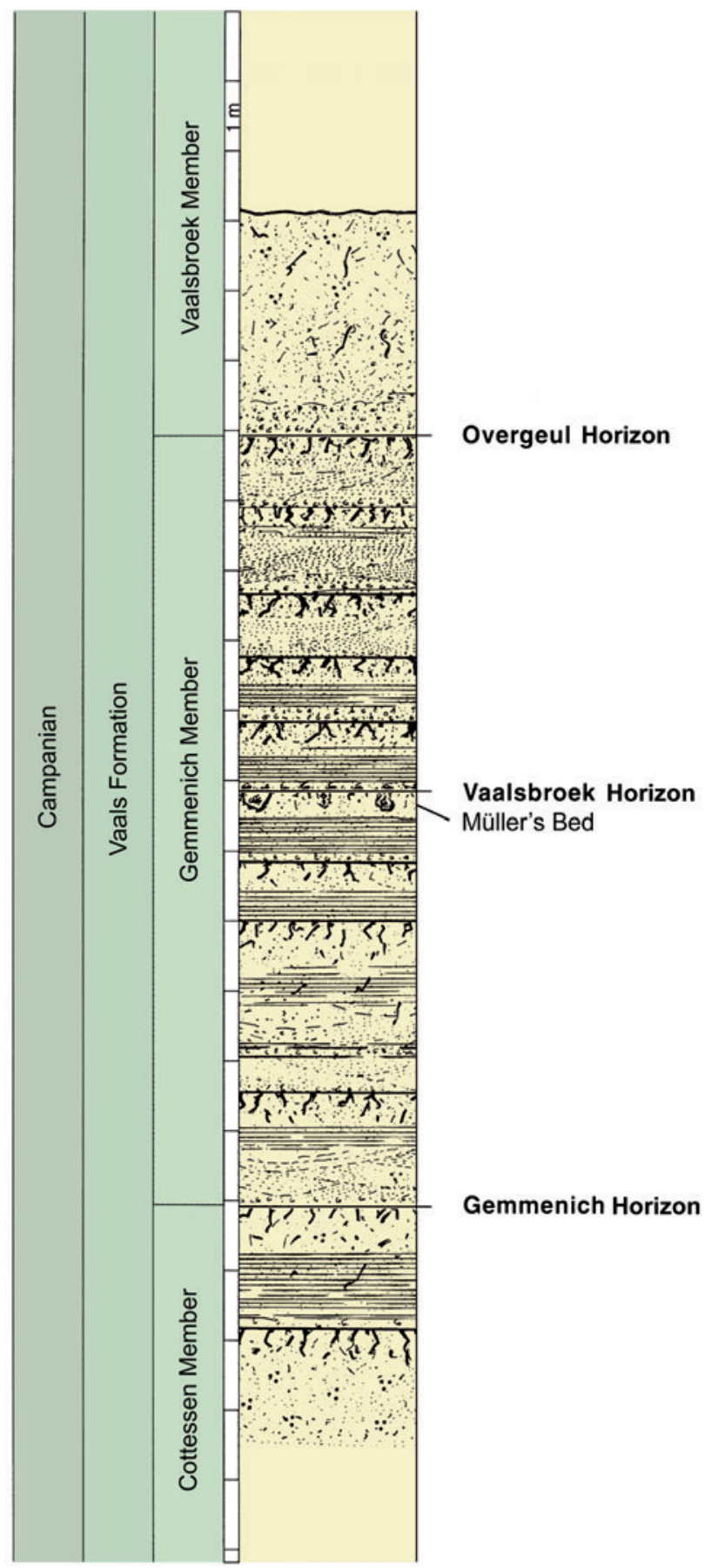

Fig. 2. Stratigraphy of the Vaals Formation (Gemmenich Member) as exposed temporarily at Vaals-Eschberg. 'Het Laagje van Müller' ('Müller's Bed) is directly below the Vaalsbroek Horizon (modified from Felder \& Bosch, 2000, fig. 3.18).

\section{Type species}

Hemiaster leymerii Desor in Agassiz \& Desor, 1847, by original designation.

\section{Diagnosis}

A hemiasterid with very short posterior petals and large inflated anterior petals, the posterior petals being shorter in length than the anterior petals are broad. Anterior sulcus more or less 
wanting at ambitus. Labral plate flask-shaped with strongly concave posterior; sternal plates strongly asymmetrical (Smith \& Wright, 2008, p. 623).

Leymeriaster campestris $s p$. nov.

Figs 3, 4, 5A, 6, 7A.

?1849 Spatangus cor anguinum; Debey, p. 22.

?1849 Spatangus bufo; Debey, p. 22.

?1849 'kleinen Spatangus'; Debey, p. 22.

?1886 Hemiaster?; Beissel, p. 115.

1998 Hemiaster (Leymeriaster) sp.; Van der Ham \& Jagt, p. 857 , fig. $1 \mathrm{~b}$.

2000a Leymeriaster sp. ?nov.; Jagt, p. 296, fig. $15^{*}$.

\section{Derivation of name}

The Latin epithet campestris alludes both to the former nature of the type locality (Latin: campus, French: champs, English: field, German: Feld) and to the surname Felder. Out of respect towards the late Peter Jozef (Sjeuf) Felder and Werner Maria Felder, who, around 1950, initiated the search for 'Müller's Bed' and eventually succeeded in tracing it, as well as to underline their immense contributions to both popular and professional geology and palaeontology of the Maastrichtian type area (Schins, 2008), we dedicate the new species of Leymeriaster to their memory.

\section{Types}

The holotype is NHMM 2011014 (ex H.J. Janssens Collection, VG.5441; Figs 3, 7A); paratypes are NHMM VG 3047 (W.M. Felder Collection; Figs 4, 5A, 6), NHMM 1996001 (Jagt, 2000a, fig. 15E) and NHMM 2010164.

\section{Diagnosis}

Medium-sized species of Leymeriaster with a relatively short adapical groove in ambulacrum III and strongly depressed paired petals. Pore pairs in ambulacrum III not sunken and interambulacral margins of this ambulacrum not thickened, raised and/or overhanging. Peripetalous fasciole slightly indented between anterior petals and ambulacrum III.

\section{Description}

Test length 26-33 mm; ambitus broadly ovate, not indented in ambulacrum III or barely so; width 22-32 mm (i.e., 94-100 per cent of test length; largest width in anterior series of interambulacra 1 and 4), height 19-26 mm (i.e., 69-79 per cent of test length, largest at fasciole in ambulacrum V). Apical system more or less central, obscured and/or damaged due to compression in all available material. Keel in interambulacrum 5 prominent in a single, barely compressed specimen. Anterior side of test regularly rounded from ambitus to apical system. Posterior side inclined anteriorly. Oral side slightly convex.
Ambulacrum III with a distinct groove adapically of fasciole; length of groove 7-10 mm (i.e., 28-31 per cent of test length), width 2-2.5 mm (i.e., 7-8 per cent of test length). Poriferous zones in groove with up to 24 pore pairs (test length $=32 \mathrm{~mm}$ ); each pore pair with an interporal granule; outer pores not in small grooves, and adjacent interambulacral margins not thickened, raised and/or overhanging; interporiferous zone 34 times wider than a single poriferous zone, densely covered with miliary tubercles and/or scrobiculate primary tubercles.

Anterior petals strongly depressed, bordered by slightly thickened, raised interambulacral margins, much longer than posterior ones, making an angle of c. $90^{\circ}$; length $9.5-13.5 \mathrm{~mm}$ (i.e., 35-42 per cent of test length), width up to $4 \mathrm{~mm}$ (i.e., c. 12 per cent of test length). Poriferous zones within a petal similar, up to 34 pore pairs in each; inner rows with elliptical pores, outer ones with ovate pores ('blunt'side outwards); pores within a pair conjugate by a shallow elongate depression, the interporal distance exceeding pore length 2-3 times; interporiferous zone about as wide as a single poriferous zone, densely covered with miliary tubercles.

Posterior petals strongly depressed, not bordered by raised interambulacral margins, ovate, making an angle of c. $90^{\circ}$; length 3-4 mm (i.e., 11-15 per cent of test length; $=26-36$ per cent of test length of anterior petal length). Poriferous zones flexed, up to 13 pore pairs in each.

Peristome at 24-28 per cent of test length from anterior side, nearly kidney shaped, bordered by a low rim; width $5.2 \mathrm{~mm}$ (test length $=32 \mathrm{~mm}$ ). Labrum protruding into peristome, with 3-6 primary tubercles; lateral-posterior extensions in contact with two complete and $3 / 5$ to $4 / 5$ of the third ambulacral plate of ambulacra I and V. Phyllode with 10-14 isopores in ambulacra II and IV, and 4-6 isopores in ambulacra I, III and V (two in each first adlabral plate in I and V). Suture between plastronal plates not distinct in available material.

Periproct high on posterior side, almond-shaped; height $3 \mathrm{~mm}$, width $2 \mathrm{~mm}$ (test length $=33 \mathrm{~mm}$ ).

Primary tubercle density c. 4 per square millimetre in ambital zone, up to c. 9 per square millimetre towards apical system, and c. 1 per square millimetre towards peristome. Tubercles scrobiculate; scrobicules tetragonal to hexagonal, closely packed in more or less distinct rows. Miliary tubercles occur in the petals, anterior groove and in adoral parts of all ambulacra, and mixed with small primaries in ambulacrum III between anterior groove and ambitus; miliary tubercles mixed with relatively large primaries (1-2 per square millimetre) occur on the labrum and on either side of ambulacrum III between the ambitus and the anterior groove. Scattered miliaries may be present on the adoral parts of all interambulacra. Interambulacral plates with a slightly raised 'centre'.

Peripetalous fasciole trapezoidal, slightly indented between anterior and posterior petals, and between anterior petals and ambulacrum III.

* References to specimens illustrated by Jagt (2000a, fig. 15) need correction, as follows: A, B = NHMM 2011 014; C, D = NHMM VG 3047 ; E = NHMM 1996001. 


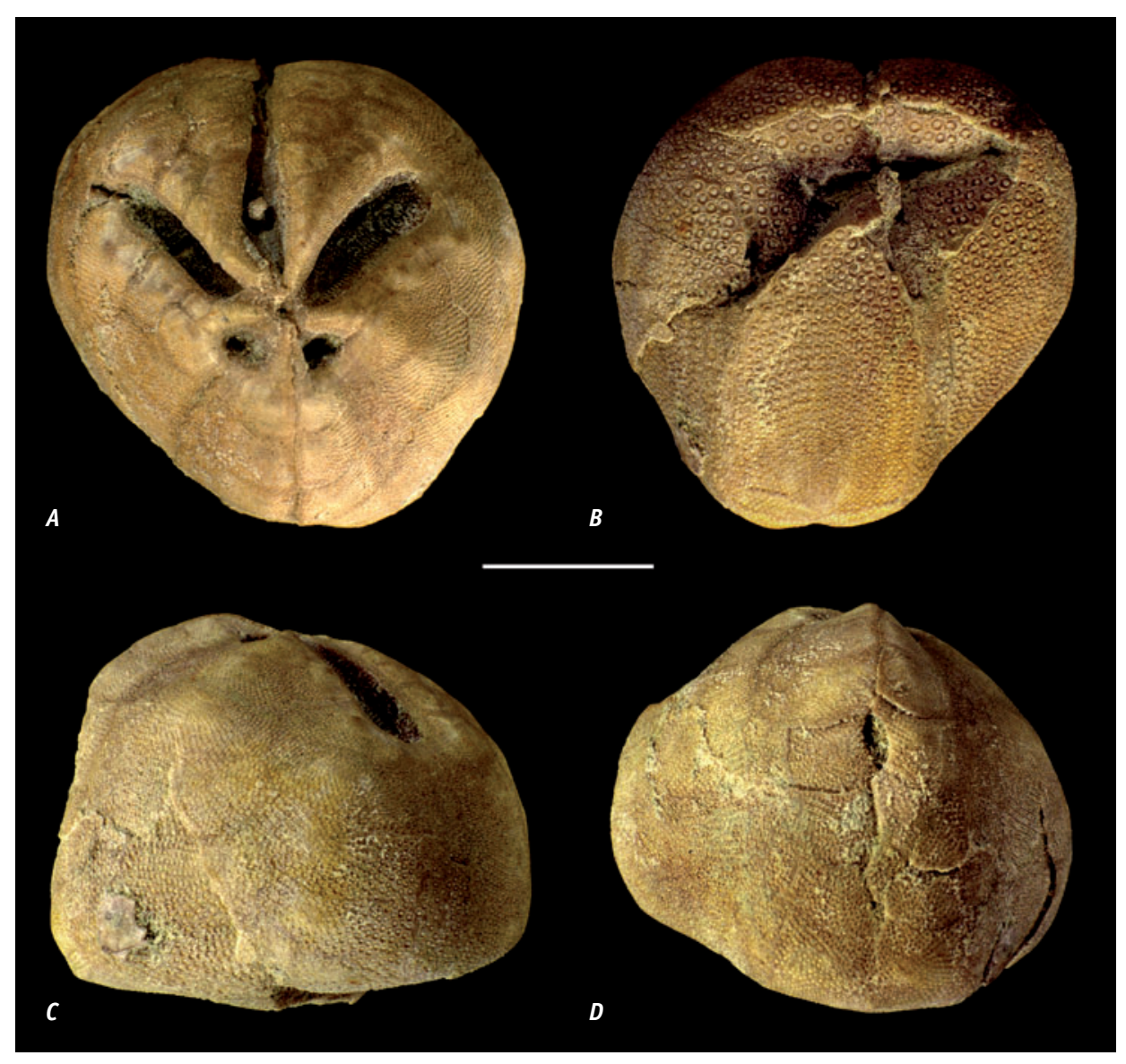

Fig. 3. Holotype of Leymeriaster campestris sp. nov. (NHMM 2011 014) in various aspects. Scale bar equals $10 \mathrm{~mm}$.

Fig. 4. One of the three paratypes of Leymeriaster campestris $s p$. nov. (NHMM VG 3047 (W.M. Felder Collection)) in various aspects. Scale bar equals $10 \mathrm{~mm}$.

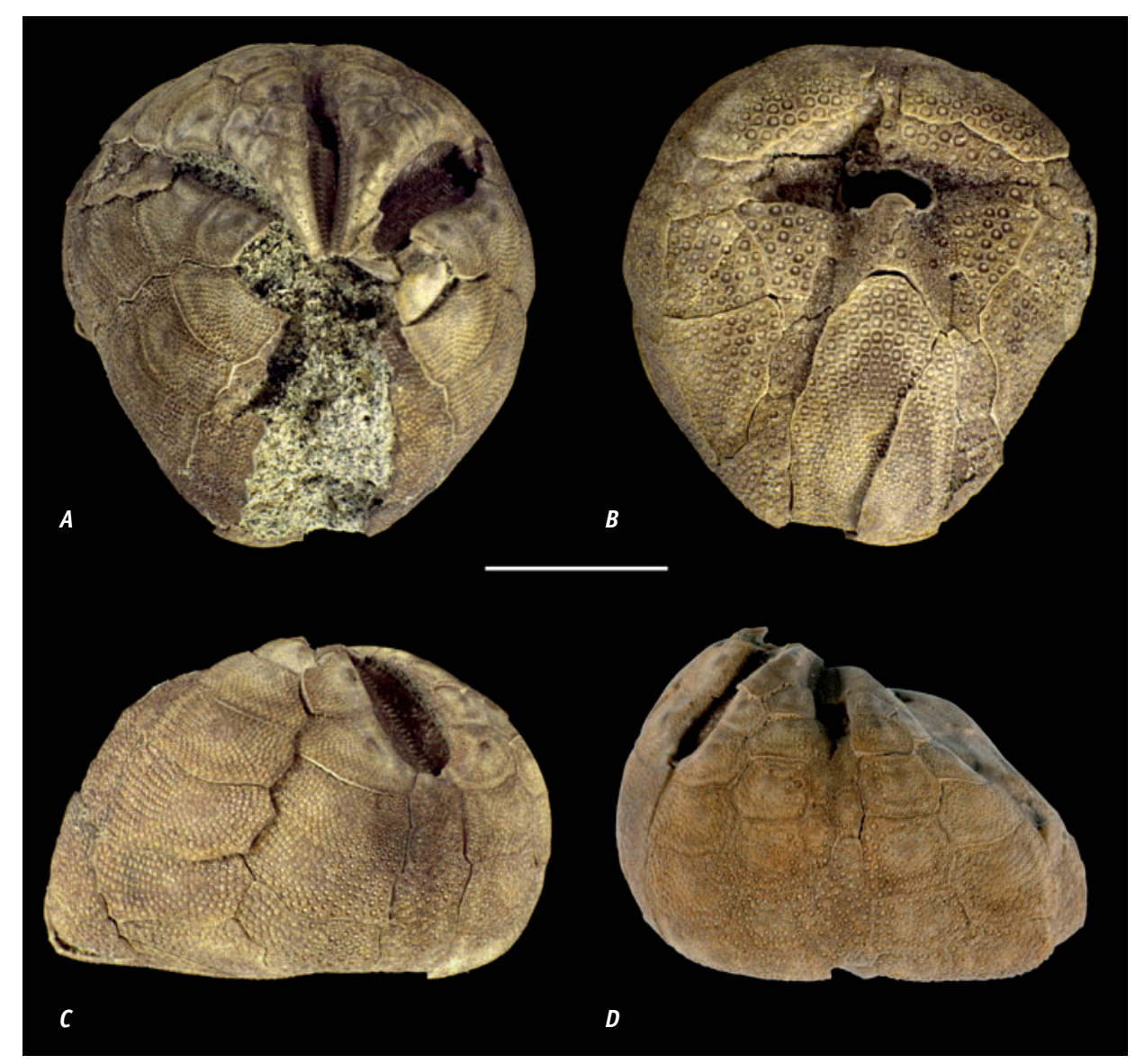




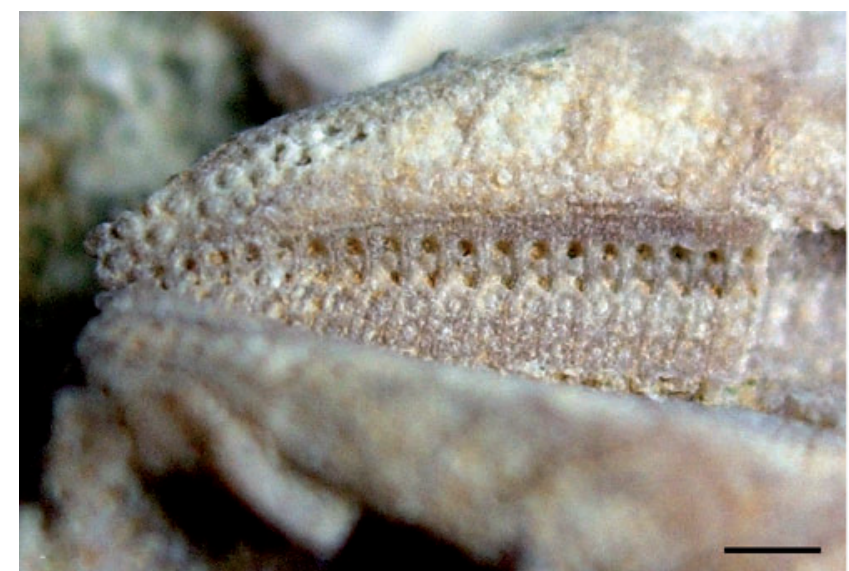

a.

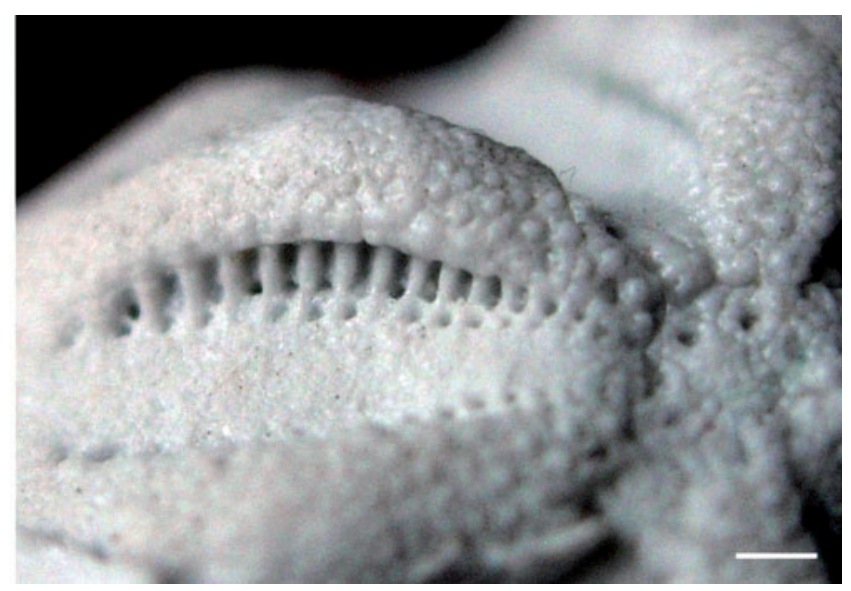

b.

Fig. 5. Detail of frontal groove in ambulacrum III. a. Leymeriaster campestris sp. nov. (NHMM VG 3047 (W.M. Felder Collection)), showing that the pore pairs are not in small depressions and the adjacent interambulacral margin is not thickened and raised (apical system to the left); $b$. Leymeriaster eluvialis (see Van der Ham, 1995, pl. 2, fig. 6) showing pore pairs in small depressions ('fossettes spéciales') and adjacent interambulacral margin thickened and raised (apical system to the right). Scale bar equals $1 \mathrm{~mm}$.

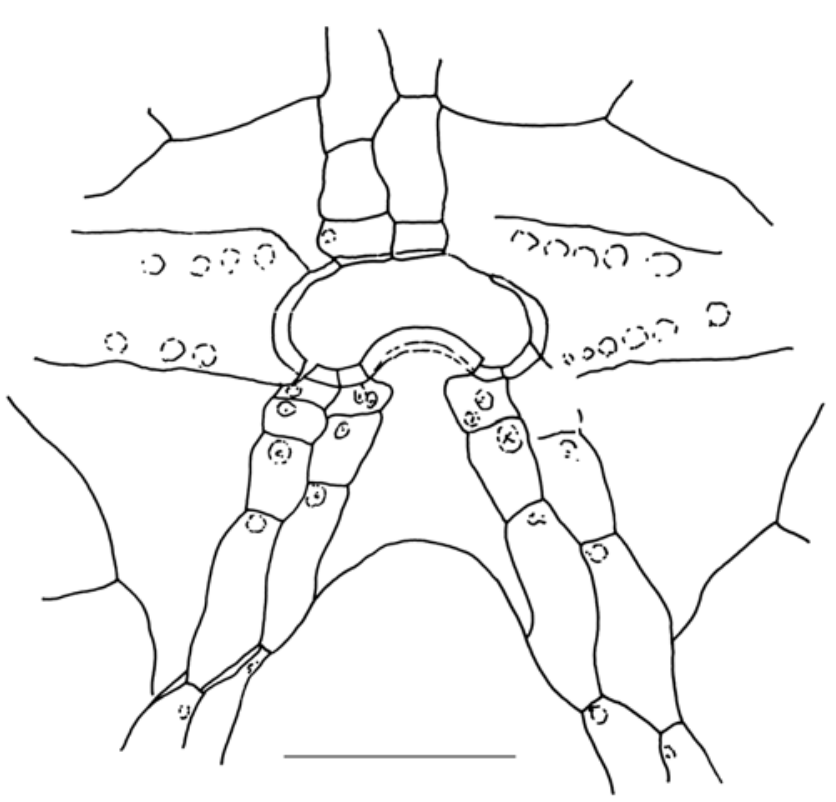

Fig. 6. Peristome plating of Leymeriaster campestris sp. nov. (NHMM VG 3047 (W.M. Felder Collection)). Scale bar equals $5 \mathrm{~mm}$.

\section{Discussion}

Lambert \& Thiéry (1924) listed eighteen species in the subgenus Hemiaster (Leymeriaster). Subsequently, Tanaka (1984) added two from the Campanian of Japan, and Van der Ham (1995) one from the upper Maastrichtian of northeast Belgium and the southeast Netherlands. After having excluded a few marginal forms and poorly known species, and following transfer of several others to the genus Opissaster Pomel, 1883 and the
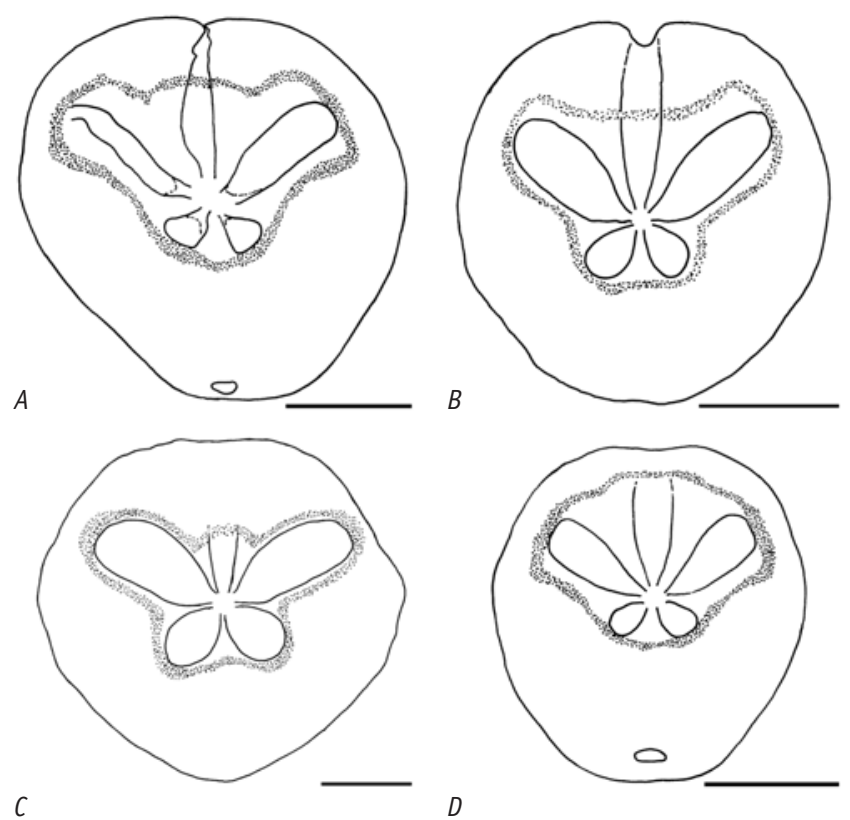

Fig. 7. Peripetalous fasciole of Leymeriaster campestris sp. nov. (A) (NHMM 2011 014, holotype), compared to that of L. maestrichtensis (B) (see Van der Ham, 1995, fig. 4b), L. eluvialis (C) (see Van der Ham, 1995, fig. 4a) and L. leymerii (D) (lower Turonian, Briollay, Anjou, France). Scale bar equals $10 \mathrm{~mm}$.

subgenus Hemiaster (Bolbaster) Pomel, 1869, Néraudeau (1990, pp. 161, 166; see also 1994) and Van der Ham (1995) recognised seven species in the Upper Cretaceous of northwest Europe. Arranged more or less in the order of their first stratigraphic appearances, these are the following: 
H. (L.) similis (d'Orbigny, 1855)

H. (L.) leymerii (Desor in L. Agassiz \& Desor, 1847)

H. (L.) nucleus (Desor in L. Agassiz \& Desor, 1847)

H. (L.) sanctipaterni (Lambert, 1911)

H. (L.) moulinsanus (d'0rbigny, 1855)

H. (L.) eluvialis Van der Ham, 1995

H. (L.) maestrichtensis (Schlüter, 1897)

1 Lambert \& Thiéry (1924)

2 D. Néraudeau (pers. comm., 1996)

Smith \& Jeffery (2000) raised Leymeriaster to the genus level, with which Jagt (2000a) concurred. Smith \& Wright (2008) listed five species of Leymeriaster, namely $L$. leymerii, $L$. similis, $L$. maestrichtensis, L. eluvialis and L. sexangulatus (d'0rbigny, 1855), the last-named being from Maastrichtian strata of Turkey and India.

According to D. Néraudeau (pers. comm., 1991, 1996), L. similis, L. leymerii, L. nucleus and L. moulinsanus are closely related, while the last-named is close to L. maestrichtensis. This, together with the stratigraphical ranges of these species, would testify to a gradual evolution from $L$. similis to $L$. maestrichtensis (see also Néraudeau, 1990, p. 165). Leymeriaster sanctipaterni might be close to L. nucleus (see Cotteau \& Triger, 1860; Lambert \& Thiéry, 1924) and L. eluvialis is considered to be a descendant of the moulinsanus-maestrichtensis lineage (Van der Ham, 1995).

Two groups can be distinguished within Leymeriaster in northwest Europe: the leymerii group (L. similis, L. leymerii, L. nucleus, L. sanctipaterni) and the maestrichtensis group (L. moulinsanus, L. eluvialis, L. maestrichtensis). The species of the latter group differ from those of the former in having a relatively short groove in ambulacrum III, in which the pore pairs are separated by small ridges, as if they are placed in small depressions (Fig. 5B; compare d'0rbigny, 1855, p. 247,'fossettes spéciales'), and in having a short labrum that protrudes into the peristome. In addition, the species of the maestrichtensis group show an indented anterior part of the peripetalous fasciole (Fig. 7; see also Van der Ham 1995; Van der Ham \& Jagt, 1998; Jagt, 2000a), which might be morphologically correlated with the limited length of the groove in ambulacrum III.

Leymeriaster campestris sp. nov. resembles members of the leymerii group in not having the pore pairs in ambulacrum III in 'fossettes spéciales' and not having thickened, raised and/or overhanging adjacent interambulacral margins (Fig. 5A). However, the relatively short groove in ambulacrum III, the short labrum that protrudes into the peristome and the indented anterior part of the peripetalous fasciole are shared with the maestrichtensis group (Figs 6, 7; see also Van der Ham 1995; Van der Ham \& Jagt, 1998; Jagt, 2000a). Leymeriaster campestris differs from $L$. eluvialis in the presence of a distinctly longer groove in ambulacrum III, and from L. maestrichtensis by the lack of a clear notch in the ambitus in ambulacrum III (Figs 3, 4, 7).
Also stratigraphically, L. campestris sp. nov. takes an intermediate position between the leymerii group and the maestrichtensis group, although the exact stratigraphical range of $L$. moulinsanus is not known. The early Campanian L. campestris sp. nov. might be an early offshoot of the maestrichtensis group, displaying several features of this group, but 'still' lacking the 'fossettes spéciales'. Leymeriaster campestris sp. nov. is the first undoubted species of Campanian Leymeriaster known from northwest Europe.

\section{Acknowledgements}

We thank D. Néraudeau (Laboratoire Géosciences, Université de Rennes) for providing comparative specimens of Leymeriaster leymerii and for general data, B.N. Kieft (Netherlands Centre for Biodiversity Naturalis, section NHN, Leiden) for final preparation of the illustrations, and Andreas Kroh (Naturhistorisches Museum Wien) and Andrew B. Smith (The Natural History Museum, London) for valuable comments on an earlier typescript.

\section{References}

Agassiz, L., 1840. Catalogus systematicus ectyporum echinodermatum fossilium musei neocomiensis, secundum ordinem zoologicum dispositus. Olivier Petitpierre (Neuchâtel): 1-20.

Agassiz, L. \& Desor, E., 1847. Catalogue raisonné des espèces, des genres, et des familles d'échinides. Annales des Sciences naturelles (Zoologie) (3)7: 129168; (3)8: 5-35, 355-380.

Beissel, I., 1886. Der Aachener Sattel und die aus demselben vorbrechenden Thermalquellen. J.A. Mayer (Aachen): 1-338.

Clark, H.L., 1917. Hawaiian and other Pacific echini. Spatangina. Memoirs of the Museum of Comparative Zoology at Harvard College 46: 81-283.

Cotteau, G.H. \& Triger, J., 1857-1869. Échinides du département de la Sarthe, considérés au point de vue zoologique et stratigraphique. J.-B. Baillière et fils (Paris): $\mathrm{xv}+1-458$.

Debey, M.H., 1849. Entwurf zu einer geognostisch-geogenetischen Darstellung der Gegend von Aachen. Boisserée (Aachen): 1-67.

d’Orbigny, A., 1855. Paléontologie Française. Terrains Crétacés 6, Échinodermes. V. Masson (Paris): 129-256.

Felder, W.M., 1980. Krijt. In: Kuyl, 0.S. (ed.): Toelichtingen bij de geologische kaart van Nederland, 1:50.000, blad Heerlen. Rijks Geologische Dienst (Haarlem): 31-53. 
Felder, W.M., 1987. Een oude fossielvindplaats in de Formatie van Vaals herontdekt. Sprekende Bodem 31: 38-39.

Felder, W.M. \& Bosch, P.W., 2000. Geologie van Nederland, deel 5. Krijt van Zuid Limburg. Nederlands Instituut voor Toegepaste Geowetenschappen TNO (Delft/Utrecht): 1-192.

Fischer, A.G., 1966. Spatangoida. In: Moore, R.C. (ed.): Treatise on Invertebrate Paleontology, Part U3(2). Geological Society of America (Boulder)/The University of Kansas Press (Lawrence): U543-U633.

Goldfuss, A., 1829. Petrefacta Germaniae tam ea, quae in museo universitatis regiae Borussicae Fridericiae Wilhelmiae Rhenanae servantur quam alia quae cunque in museis hoeninghausiano, muensteriano aliisque extant, iconibus et descriptionibus illustrata. Abbildungen und Beschreibung der Petrefacten Deutschlands und der angränzenden Länder, unter Mitwirkung des Herrn Grafen Georg zu Münster. Arnz \& Co. (Düsseldorf): 77-164, pls 26-50.

Holzapfel, E., 1887-1889. Die Mollusken der Aachener Kreide, I. Abtheilung, Cephalopoden und Glossophora; II. Lamellibranchiata. Palaeontographica 34: 39-180; 35: 159-268.

Jagt, J.W.M., 1999. Late Cretaceous-Early Palaeogene echinoderms and the K/T boundary in the southeast Netherlands and northeast Belgium - Part 1: Introduction and stratigraphy. Scripta Geologica 116: 1-57.

Jagt, J.W.M., 2000a. Late Cretaceous-Early Palaeogene echinoderms and the K/T boundary in the southeast Netherlands and northeast Belgium - Part 4: Echinoids. Scripta Geologica 121: 181-375.

Jagt, J.W.M., 2000b. Late Cretaceous-Early Palaeogene echinoderms and the K/T boundary in the southeast Netherlands and northeast Belgium - Part 3: Ophiuroids. With a chapter on: Early Maastrichtian ophiuroids from Rügen (northeast Germany) and Møn (Denmark) by Manfred Kutscher and John W.M. Jagt. Scripta Geologica 121: 1-179.

Kennedy, W.J. \& Jagt, J.W.M., 1995. Lower Campanian heteromorph ammonites from the Vaals Formation around Aachen, Germany, and adjacent parts of Belgium and the Netherlands. Neues Jahrbuch für Geologie und Paläontologie Abhandlungen 197: 275-294.

Lambert, J., 1911. Étude sur les échinides crétacés de Rennes-les-Bains et des Corbières. Bulletin de la Société d'Études scientifiques de l'Aude 22: 1-120.

Lambert, J. \& Thiéry, P., 1909-1924. Essai de nomenclature raisonnée des échinides. L. Ferrière (Chaumont): iii + 1-607.

Meijer, M., 1955. Sur un échinide peu connu du Maestrichtien du Limbourg hollando-belge. Hemiaster (Leymeriaster) maestrichtensis Schlueter. Natuurhistorisch Maandblad 44: 74-77.

Müller, J., 1847. Monographie der Petrefacten der Aachener Kreideformation. Erste Abtheilung mit 2 lithografirten Tafeln. Henry \& Cohen (Bonn): 1-48.

Müller, J., 1851. Monographie der Petrefacten der Aachener Kreideformation. Zweite Abtheilung mit 4 lithografirten Tafeln. Henry \& Cohen (Bonn): 1-88.

Müller, J., 1859. Monographie der Petrefacten der Aachener Kreideformation. Supplementheft zur ersten und zweiten Abtheilung mit zwei in Stein radirten Tafeln. J.A. Mayer (Aachen): 1-32.

Néraudeau, D., 1990. Ontogenèse, paléoécologie et histoire des Hemiaster, échinides irréguliers du Crétacé. Université de Bourgogne (Dijon): 1-194. (unpublished PhD thesis).

Néraudeau, D., 1994. Hemiasterid echinoids (Echinodermata: Spatangoida) from the Cretaceous Tethys to the present-day Mediterranean. Palaeogeography, Palaeoclimatology, Palaeoecology 110: 319-344.
Pomel, A., 1869. Revue des échinodermes et de leur classification pour servir d'introduction à l'étude des fossiles. Deyrolle (Paris): 1-67.

Pomel, A., 1883. Classification méthodique et genera des échinides, vivants et fossiles. A. Jourdan (Alger): 1-131.

Schins, W., 2008. Het Fenomeen Felder. De geologische passie van twee Limburgse mijnwerkers. Nederlandse Geologische Vereniging, Afdeling Limburg (Valkenburg aan de Geul): 1-254.

Schlüter, C., 1883. Die regulären Echiniden der norddeutschen Kreide. I. Glyphostoma (Latistellata). Abhandlungen der königlich preussischen geologischen Landesanstalt 4: iv + 1-72.

Schlüter, C., 1897. Ueber einige exocyclische Echiniden der baltischen Kreide und deren Bett. Zeitschrift der deutschen geologischen Gesellschaft 49: 18-50.

Schlüter, C., 1899. Ueber einige von Goldfuss beschriebene Spatangiden, II. Stück. Zeitschrift der deutschen geologischen Gesellschaft 51: 104-124.

Smith, A.B. \& Jeffery, C.H., 2000. Maastrichtian and Palaeocene echinoids: a key to world faunas. Special Papers in Palaeontology 63: 1-406.

Smith, A.B. \& Wright, C.W., 2003. British Cretaceous echinoids. Part 7, Atelostomata, 1. Holasteroida. Monograph of the Palaeontographical Society London 156 (619): 440-568.

Smith, A.B. \& Wright, C.W., 2008. British Cretaceous echinoids. Part 8, Atelostomata, 2. Spatangoida (1). Monograph of the Palaeontographical Society London 162 (630): 569-635.

Tanaka, K., 1984. Hemiasterid echinoids from the Upper Cretaceous of Japan. Transactions and Proceedings of the Palaeontological Society of Japan 135: 427-444.

Van Birgelen, M., 1989. Ophiura fürstenbergii Müller 1847, na 140 jaar opnieuw gevonden. Sprekende Bodem 33: 17-18.

Van der Ham, R.W.J.M., 1995. Hemiaster (Leymeriaster) eluvialis, a new echinoid from the late Maastrichtian of NE Belgium and SE Netherlands. Bulletin de l'Institut des Sciences naturelles de Belgique, Sciences de la Terre 65: 153-164.

Van der Ham, R.W.J.M. \& Jagt, J.W.M., 1998. Late Cretaceous hemiasterid echinoids from the Maastrichtian type area. In: Mooi, R. \& Telford, M. (eds): Echinoderms: San Francisco. A.A. Balkema (Rotterdam/Brookfield): 857-862.

Woodward, S., 1833. An outline of the geology of Norfolk. Longman \& Co. (London): 1-55. 